Biogeosciences Discuss., 6, 1747-1776, 2009

www.biogeosciences-discuss.net/6/1747/2009/

(C) Author(s) 2009. This work is distributed under

\title{
A process-based model to estimate gas exchange and monoterpene emission rates in the mediterranean maquis - comparisons between modelled and measured fluxes at different scales
}

M. Vitale ${ }^{1}$, G. Matteucci ${ }^{2}$, S. Fares ${ }^{2, *}$, and B. Davison ${ }^{3}$

${ }^{1}$ Dept. of Plant Biology, University of Rome Sapienza, Piazzale Aldo Moro 5, 00185 Rome, Italy

${ }^{2}$ National Research Council, Institute of Agro-environmental and Forest Biology, Via Salaria km. 29, 300, 00016 Monterotondo Scalo, Rome, Italy

${ }^{3}$ Lancaster Environment Centre, Lancaster University, Lancaster LA1 4YQ, UK

*now at: University of California, Dept. of Environmental Science, Policy, and Management, 137 Mulford Hall, Berkeley, CA 94720, USA

Received: 1 December 2008 - Accepted: 17 December 2008 - Published: 6 February 2009 Correspondence to: M. Vitale (marcello.vitale@uniroma1.it)

Published by Copernicus Publications on behalf of the European Geosciences Union.

Modelling of gas exchange and monotepene fluxes

M. Vitale et al.

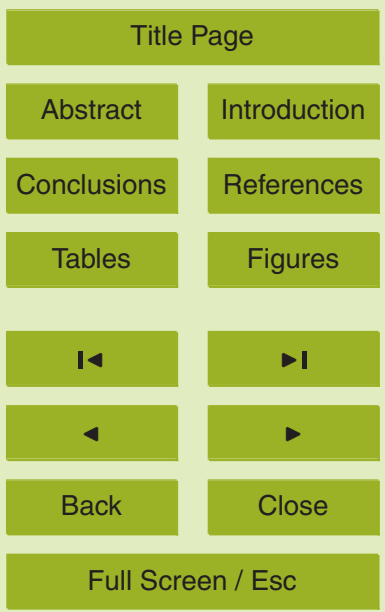

Printer-friendly Version 


\section{Abstract}

This paper concerns the application of a process-based model (MOCA, Modelling of Carbon Assessment) as an useful tool for estimating gas exchange, and integrating the empirical algorithms for calculation of monoterpene fluxes, in a Mediterranean maquis 5 of central Italy (Castelporziano, Rome). Simulations were carried out for a range of hypothetical but realistic canopies of the evergreen Quercus ilex (holm oak), Arbutus unedo (strawberry tree) and Phillyrea latifolia. More, the dependence on total leaf area and leaf distribution of monoterpene fluxes at the canopy scale has been considered in the algorithms. Simulation of the gas exchange rates showed higher values for

$P$. latifolia and $A$. unedo $\left(2.39 \pm 0.30\right.$ and $3.12 \pm 0.27 \mathrm{gC} \mathrm{m}^{-2} \mathrm{~d}^{-1}$, respectively) with respect to $Q$. ilex $\left(1.67 \pm 0.08 \mathrm{gC} \mathrm{m}^{-2} \mathrm{~d}^{-1}\right)$ in the measuring campaign (May-June). Comparisons of the average Gross Primary Production (GPP) values with those measured by eddy covariance were well in accordance $\left(7.98 \pm 0.20\right.$ and $6.00 \pm 1.46 \mathrm{gC} \mathrm{m}^{-2} \mathrm{~d}^{-1}$, respectively, in May-June), although some differences (of about $30 \%$ ) were evident

15 in a point-to-point comparison. These differences could be explained by considering the non uniformity of the measuring site where diurnal winds blown S-SW direction affecting thus calculations of $\mathrm{CO}_{2}$ and water fluxes. The introduction of some structural parameters in the algorithms for monoterpene calculation allowed to simulate monoterpene emission rates and fluxes which were in accord to those measured $(6.50 \pm 2.25$ 20 vs. $9.39 \pm 4.5 \mu \mathrm{g} \mathrm{g}_{\mathrm{DW}}^{-1} \mathrm{~h}^{-1}$ for $Q$.ilex, and $0.63 \pm 0.20 \mu \mathrm{g} \mathrm{g}_{\mathrm{DW}}^{-1} \mathrm{~h}^{-1}$ vs. $0.98 \pm 0.30 \mu \mathrm{g} \mathrm{g}_{\mathrm{DW}}^{-1} \mathrm{~h}^{-1}$ for $P$. latifolia). Some constraints of the MOCA model are discussed, but it is demonstrated to be an useful tool to simulate physiological processes and BVOC fluxes in a very complicated plant distributions and environmental conditions, and necessitating also of a low number of input data.

\section{BGD}

6, 1747-1776, 2009

\section{Modelling of gas exchange and monotepene fluxes}

M. Vitale et al.

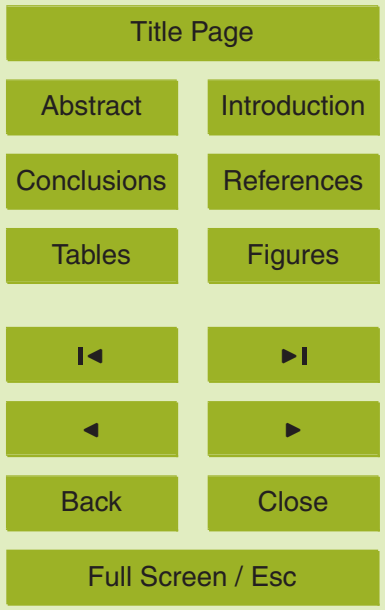

Printer-friendly Version

Interactive Discussion 


\section{Introduction}

In the last decades research have been done by the scientific community to understand the plant community's response to occurring climatic change, at different spatial and temporal scales (Schwalm and Ek, 2001; Jump and Peñuelas, 2005; Diffenbaugh et al., 5 2005; Parmesan, 2006). A representative description of the land surface - atmosphere interaction requires mathematical models that are able to describe the physical and biological processes in vegetation cover and soil, as well as physical processes in the atmospheric boundary layer. Early models were closely connected with development of weather and climate forecast models, as well as productivity models for agricultural crops (Sellers et al., 1997). A need for an increase in accuracy of model predictions, an expansion of the areas of the model applications and progress in computer technology led to the intensive development of the modelling approaches. A suite of process models is available to predict short-and longer-term $C$ fluxes in forest trees, stands, and ecosystems. They address specific, and often rather narrow, questions of interest defined by the study objectives and the experimental design of field research sites. For instance, short-term gas exchange may be studied using detailed canopy models such as MAESTRO (Wang and Jarvis, 1990) or MAESTRA (Luo et al., 2001). Longer-term (days to years) simulations are more suited to stand- or ecosystem-scale models such as SECRETS (Sampson et al., 2001), BIOMASS (McMurtrie and Landsberg, 1992), BIOME-BGC (Running and Hunt, 1993) or PnET (Aber and Federer, 1992), to name a few. It is not surprising, then, that these models vary in their outputs, time-step, and process resolution. Canopy models accurately predict instantaneous radiation at the leaf surface (and thus $\mathrm{CO}_{2}$ exchange) (Wang and Jarvis, 1990), however they, naturally, lack a unified approach for long-term $\mathrm{C}$ allocation. Conversely, ecosystem models such as BIOME-BGC - a "big leaf" model - allocate $C$ and they estimate daily fluxes but finer resolution underpinnings are, by design, ignored, and thus cannot be validated (de Pury and Farquhar, 1997). Ecosystem models are used to synthesize and integrate knowledge gained from intensive, short-term monitoring and experimentation

BGD

6, 1747-1776, 2009

\section{Modelling of gas exchange and monotepene fluxes}

M. Vitale et al.

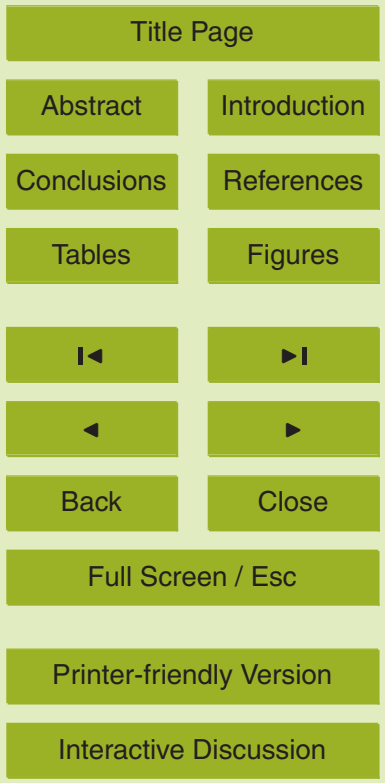

Interactive Discussion 
- such as eddy-covariance measurements - to extrapolate to broader landscapes for long-term projections. Developing these models in concert with direct measures of gas exchange (Lai et al., 2002) has provided a means to validate short-term (days to years) model outputs (Wang et al., 2004). However, up-scaling processes that occur 5 at small-scales (leaves) to large spatial and temporal-scales (ecosystems) is subject to large errors due to functional non-linearity and heterogeneity in the distribution of processes (Jarvis, 1995). Canopy models that link the terrestrial biosphere to atmosphere can be categorized as either multi-layer or big-leaf models. A multi-layer model integrates the fluxes from each layer to give the total flux (Leuning et al. 1995), while 10 the big-leaf approach maps properties of the whole canopy onto a single leaf to calculate the flux (Bonan, 1996; Dickinson et al., 1998). These methods necessarily use different parameterizations for the non-linear relationships that govern assimilation and transpiration. The multi-layer models can use parameters that are measured at the leaf level. The big-leaf models require parameters at the canopy level that cannot be mea15 sured directly, nor defined as the arithmetic mean of leaf level parameters because of non-linearity (Wang et al., 2001). Big-leaf models have been extensively used in land surface climate modelling (Bonan 1996; Dickinson et al., 1998; Dai et al., 2003). They require fewer parameters and are economical in computer time than the multi-layer models. They treat the canopy as single big-leaf with the fluxes of leaf energy, water and $\mathrm{CO}_{2}$ calculated by coupled equations. In this context, Wang and Leuning (1998) developed a more comprehensive two-leaf approach with the canopy described by variables and parameters that represent the bulk properties of all sunlit or shaded leaves, using the Goudriaan and van Larr (1994) radiation model to estimate the total amount of radiation. Direct sunshine heats leaves more than the scattered light in the shade, 25 and, as a consequence, the net photosynthetic rate of sunlit leaves is relatively high due to light saturation but there is a drastic reduction in net photosynthesis with the low light levels of shaded leaves. If such differences in physiological properties of leaves and the differences in light and temperatures between sunlit and shaded leaves are neglected, the estimates of photosynthesis and energy fluxes for the canopy may be

BGD

$6,1747-1776,2009$

\section{Modelling of gas exchange and monotepene fluxes}

M. Vitale et al.

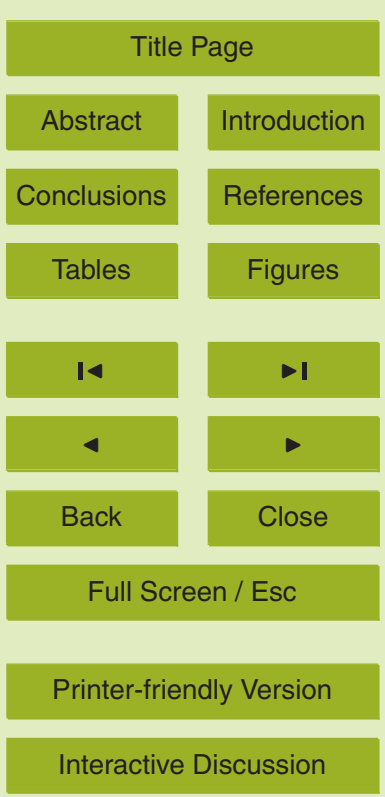

1750 
significantly in error. However, several researches have been carried out to minimize the big leaf's errors, producing some models characterized by an integration of properties related both to the big-leaf approach and two-leaf approach (Schymanski et al., 2007). Ideally, canopy photosynthesis would be computed as the sum of photosyn5 thesis rates over all leaves, where each leaf would absorb a certain amount of light and would have a certain biochemical capacity and stomatal conductivity. As a compromise, it is assumed that the canopy is composed of leaves that are horizontal and randomly distributed in homogeneous layers of foliage for light processing purposes, but considered the canopy as a single big-leaf for gas exchange purposes. Finally, 10 up-scaling exercises from leaf to canopy level could be realized by integration of several methodologies operating at different temporal and spatial scales (Baldocchi et al., 1999; Ciccioli et al., 2003; Chiesi et al., 2007) but also by using process-based models which were helpful to estimate physiological variables at different temporal and spatial resolutions (Lloyd and Farquhar, 1996; Cao and Woodward, 1998; Anselmi et al., 2004; El Maayar and Chen, 2006). The brief description about different approaches to the modelling of gas exchange rates does not address to the better modelling approach, because this depends on to the vegetation type considered in each study case. In this paper, a process-based model, MOCA (Modelling of Carbon Assessment) has been used to estimate gas exchange rates from three plant species (Quercus ilex L.; Arbutus unedo L. and Phillyrea latifolia L.) growing in the Mediterranean maquis located on the dune-like system of the Castelporziano estate (Western Italy). The use of one-dimensional big-leaf model in this study, it was imposed by the well characterised morpho-structural properties of the Mediterranean vegetation and, in particular, of the dunal-system vegetation maquis, which made extremely difficult to apply either a multilayer-based approach, or also a two-leaf-based approach, given a generally low persistence of shaded and mature leaves in the maquis vegetation canopies (Gratani and Bombelli, 2000) and the dis-homogeneous canopy structures of the study site (Fares et al., 2009). Inside the sub-modules of MOCA, modules concerning the calculation of monoterpene fluxes has been added, linking them to some structural pa-

BGD

6, 1747-1776, 2009

\section{Modelling of gas exchange and monotepene fluxes}

M. Vitale et al.

Title Page

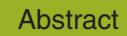

Introduction

Conclusions

Tables

References

Figures

14

4

Back

Close

Full Screen / Esc

Printer-friendly Version

Interactive Discussion 
rameters such as leaf area index and foliar density calculated, in an iteratively way, by the photosynthetic process-based model. Results of simulations will be discussed in relation to measured data at different scale and literature.

\section{Methods}

\subsection{Model concept}

The model used here was a modified version of a previous model employed to simulate functional trends under climatic changes in temperature (Vitale et al., 2003) for a Holm oak forest. The model was based on the big leaf-concept and the different physiological variables were calculated in sub-modules (Fig. 1) in the range of the sun10 light period, which is, in turn, calculated on the geographical coordinates basis for each day of the year (Vitale et al., 2005a). The model has been implemented by STELLA II package (High Performance Systems Inc., USA), an object-oriented programming software, that uses "objects" and their interactions to design applications and computer programs. In MOCA model the sub-modules are treated as objects interacting through

\section{were performed by using a Runge-Kutta interpolation of 4th order.}

\subsection{The model}

\subsubsection{Gas exchange modelling}

A process-based model, MOCA (Modelling for Carbon Assessment), has been 20 used to simulate annual net productivity (NPP, $\left.\mathrm{tC} \mathrm{ha}^{-1}\right)$ and water transpiration $(E$, $\mathrm{kg} \mathrm{H}_{2} \mathrm{O}^{-1}$ ) at canopy level (Vitale et al., 2003, 2005a, 2007). Here, MOCA has been modified to estimate NPP and $E$ for three plant species, Quercus ilex L., Arbutus unedo L. and Phillyrea latifolia L., which covered the test area for about $52 \%$. In detail, MOCA model calculates simultaneously these physiological parameters for

BGD

$6,1747-1776,2009$

Modelling of gas exchange and monotepene fluxes

M. Vitale et al.

Title Page

Abstract Introduction

Conclusions References

Tables Figures

14

$\rightarrow$

$<$

Back

Close

Full Screen / Esc

Printer-friendly Version

Interactive Discussion 
the 2007 year at the daily time scale. The daily LAI contribution $\left(\mathrm{m}^{2}{ }_{\text {leaf }} \mathrm{m}^{-2}\right.$ ground $)$ was modelled by using Eq. (1):

$\operatorname{LAl}(t)=\operatorname{SLA} \times \alpha \times P_{\mathrm{NET}}(t-1)$

where SLA is the specific leaf area $\left(\mathrm{m}^{2} \mathrm{~g}_{\mathrm{DW}}^{-1}\right), P_{\mathrm{NET}}(\mathrm{t}-1)$ is the net productivity rate of the $5 \quad(t-1)$ th day of year, and $\alpha$ is the leaf partition coefficient of the accumulated biomass, that is assumed to be 0.25 . Net productivity rate $\left(P_{\mathrm{NET}}(t), \mu \mathrm{mol} \mathrm{CO} \mathrm{m}^{-2} \mathrm{~s}^{-1}\right)$ is calculated as response to the mean light radiation inside the canopy at the $t$-th day of year $\left(Q_{i}(t)\right)$, according to de Wit et al. (1978):

\section{BGD}

$6,1747-1776,2009$

$P_{\mathrm{NET}}(t)=\left(P_{\mathrm{NET}_{\max }}-R d\right)\left[1-e^{\left(\frac{\mathrm{QYQi}(t)}{P_{\mathrm{NET}} \max }\right)}\right]+R d$

10 where $P_{\mathrm{NETmax}}$ is the maximum rate of net photosynthesis at light saturation $\left(\mu \mathrm{mol} \mathrm{CO} \mathrm{CO}^{-2} \mathrm{~s}^{-1}\right), R d$ is the dark respiration rate $\left(\mu \mathrm{mol} \mathrm{CO} \mathrm{C}^{-2} \mathrm{~s}^{-1}\right)$, and $\mathrm{QY}$ is the quantum yield efficiency of photosynthesis $\left(\mu \mathrm{mol} \mathrm{CO}_{2} \mu\right.$ mole photons $\left.{ }^{-1}\right)$. The dark respiration rate is assumed to be constant $\left(1.03 \mu \mathrm{mol} \mathrm{CO}_{2} \mathrm{~m}^{-2} \mathrm{~s}^{-1}\right)$ and integrated for the darkness period - 24-photoperiod(t).

15 The attenuation of light inside the canopy $Q_{i}(t)\left(\mu\right.$ mole photons $\left.\mathrm{m}^{-2} \mathrm{~s}^{-1}\right)$ is assumed to be dependent by the LAI ( $t$ ) according to the Beer-Lambert law (Björn and Vogelmann, 1993):

$Q_{i}(t)=Q_{o}(t) \times e^{-(k(t) \operatorname{LAl}(t))}$

where $Q_{o}(t)$ is the irradiance above the canopy ( $\mu$ mole photons $\mathrm{m}^{-2} \mathrm{~s}^{-1}$ ) for the $t$-th day of the year and $k$ is the coefficient of light extinction for a given woody vegetation structure. In our case $k$ is defined as empirical function of the previous $(t-1)$ th day leaf area index and iteratively calculated:

$k(t)=\frac{(0.75 \times \operatorname{LAl}(t-1))}{(0.40+\operatorname{LAl}(t-1))}$

Modelling of gas exchange and monotepene fluxes

M. Vitale et al.

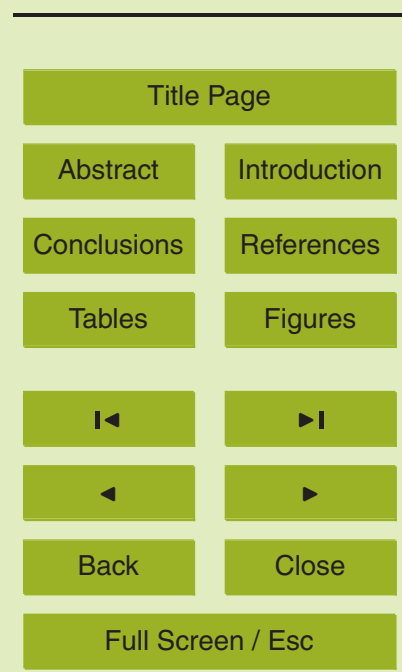

Printer-friendly Version

Interactive Discussion 
The coefficients 0.75 and 0.40 are the upper and lower limits of the coverage of plant stands previously measured by Plant Canopy Analyser device (Li-Cor 2000, Li-Cor Corp. USA).

Stomatal conductance to water vapour $\left(\mathrm{gs}, \mathrm{mol} \mathrm{m}^{-2} \mathrm{~s}^{-1}\right)$ is calculated as function of $5 \quad P_{\mathrm{NET}}(t)$, ambient $\mathrm{CO}_{2}(\mathrm{Ca}, 370 \mathrm{ppm})$ and relative humidity $(\mathrm{RH}(t)$, dimensionless $)$ after Ball et al. (1987) and Harley et al. (1992):

$g s(t)=g s_{o}+m\left(\frac{P_{\mathrm{NET}}(t) \times \mathrm{RH}(\mathrm{t})}{C a}\right)$

where $g s_{0}\left(\mathrm{~mol} \mathrm{~m}^{-2} \mathrm{~s}^{-1}\right)$ is the minimum stomatal conductance to $\mathrm{H}_{2} \mathrm{O}$ vapour when $P_{\mathrm{NET}}(t) \leq 0$ and $m$ is an empirical coefficient which represents the composite sensitivity 10 of $g s$ to $P_{\mathrm{NET}}(t), C a$ and $\mathrm{RH}(t)$.

\subsubsection{Calculations of monoterpene emission and fluxes}

Calculation of the monoterpene flux was estimated from the dimensionless emission factors and normalised emission rate, $E s$ (at $303 \mathrm{~K}_{\text {and }} 1000 \mu$ mole photons $\mathrm{m}^{-2} \mathrm{~s}^{-1}$ ) The temperature-based emission factor, $C_{\theta}(t)$, which considers the emission depending only on the foliar temperature (Tingey et al., 1980) was calculated by:

$C_{\theta}(t)=e^{\left(\beta \times\left(T_{\text {leaf }}(t)-T s\right)\right)}$

where $\beta$ ( $=0.09$ for all species) is an empirical coefficient. If monoterpene emissions depended also on light intensity $Q_{i}(t)$, previously calculated by the Beer-Lambert law, then Guenther's algorithm (Guenther et al., 1993) was used, where the dimensionless correction factors depending on temperature, $C_{T}(t)$, and on and PAR $C_{L}(t)$ (Eqs. 7 and 8 , respectively) were calculated by:

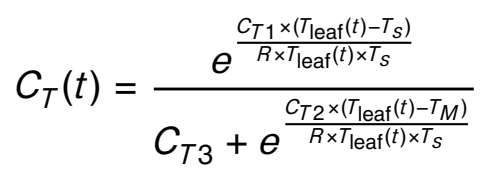

BGD

$6,1747-1776,2009$

Modelling of gas exchange and monotepene fluxes

M. Vitale et al.

Title Page

Abstract

Introduction

Conclusions

References

Tables

Figures

14

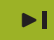

4

Back

Close

Full Screen / Esc

Printer-friendly Version

Interactive Discussion 
$c_{L}(t)=\frac{\alpha \times C_{L 1} \times Q_{i}(t)}{\sqrt{1+\alpha^{2} \times Q_{i}(t)^{2}}}$

BGD

$6,1747-1776,2009$

$R$ is the ideal gas constant $\left(=8.314 \mathrm{~J} \mathrm{~K}^{-1} \mathrm{~mol}^{-1}\right) T_{\text {leaf }}(t)$ is the leaf temperature in Kelvin, $T s(=303 \mathrm{~K})$ is the standard temperature and $T_{M}(=314 \mathrm{~K})$, $C_{T 1}\left(=95.000 \mathrm{~J} \mathrm{~mol}^{-1}\right), C_{T 2}\left(=230.000 \mathrm{~J} \mathrm{~mol}^{-1}\right), C_{T 3}(=0.961), C_{L 1}(=1.066)$ and $5 \quad \alpha(=0.0027)$ are empirical coefficients.

These algorithms were used in the monoterpene flux estimations when applied to several plant Mediterranean maquis species (Simon et al., 2006):

$F_{\text {Monot }}(t)=\left[\left(E s_{\max }\right) \times\right.$ pool $\times C_{\theta}(t)+\left(E s_{\max }\right) \times$ bio $\left.\times C_{T}(t) \times C_{L}(t)\right] \times C_{D} \times D \times r_{o}$

where $E s_{\max }\left(\mu \mathrm{g} \mathrm{g}^{-1}\right.$ dryweight $\left.\mathrm{h}^{-1}\right)$ is the maximal normalised emission rate in a year for 10 a plant species calculated according to the type of emission reference temperature of $303 \mathrm{~K}$ (Tingey et al., 1980), and a reference photosynthetically active radiation (PAR) of $1000 \mu \mathrm{mol} \mathrm{m} \mathrm{m}^{-2}$, and/or just at a reference temperature of $303 \mathrm{~K}$ (Guenther et al., 1993). In the MOCA model $E s_{\max }$ has been deduced by Eq. (10) by comparing the theoretical maximum normalised value $\left(E s_{\max }\right)$ from the seasonal emission profiles 15 with the average normalised emission rate $(E S)$ for the main plants of the studied area (Q. ilex, Q. pubescens, P. halepensis, garrigue vegetation) (Dumergues, 2003):

$E s_{\max }=1.27 \times E s$

Es assumed values of $24.9 \mu \mathrm{g} \mathrm{g}_{\mathrm{DW}}^{-1} \mathrm{~h}^{-1}$ for Q. ilex (Pio et al., 1993; Owen et al., 1997; Kesselmeier and Staudt, 1999) and $2.4 \mu \mathrm{g} \mathrm{g}_{\mathrm{DW}}^{-1} \mathrm{~h}^{-1}$ for $P$. latifolia and $A$. unedo (Simon et al., 2006).

$D$ is the foliar density $\left(g_{\text {dryweight }} \mathrm{m}^{-2}\right)$ and it is calculated through its functional linkage with the photosynthetic process-based model and LAI (t) as follows:

Modelling of gas exchange and monotepene fluxes

M. Vitale et al.

Title Page

Abstract Introduction

Conclusions References

Tables Figures

14 $\rightarrow$

4

Back

Close

Full Screen / Esc

Printer-friendly Version

Interactive Discussion

$D(t)=\operatorname{SLA}_{(j)}^{-1} \times \operatorname{LAl}(t)_{(j)}$

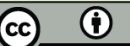


for each species $j(=3)$. $\quad C_{D}$ is the seasonal foliar biomass correction factor - deduced by Owen and Hewitt (2000), as 1 in summer and 0.8 in autumn. $r_{o}$ the escape efficiency, that is the fraction of trace gases leaving the canopy; not all trace gases emitted by vegetation enter the atmosphere because a fraction is absorbed again, or

5 reacts in some way with the canopy. Guenther et al. (2000) suggested that $95 \%$ of total isoprene emitted by the canopy enters the atmosphere, so for this compound it is only a minor effect $\left(r_{o}=0.95\right)$. However, for the other VOCs and especially for the monoterpenes, a large flux may not escape from the canopy (Goldstein et al., 2004). But, as there is no real agreement on this point, we used the same value for monoterpenes 10 as well $\left(r_{o}=0.95\right)$. The parameter bio $(=1)$ is the percentage monoterpenic emission of photosynthetic origin, and pool $(=0)$ is the percentage monoterpenic emission from pools.

The total emission TE $\left(\mu \mathrm{g} \mathrm{h}^{-1}\right)$ for all plant species occupying a territory of area $S$ $\left(\mathrm{m}^{2}\right)$ is given by:

$15 \mathrm{TE}=\sum_{t}^{1 \rightarrow 365}\left(\sum_{j}^{1 \rightarrow n} F_{\text {Monot }}(i)(t) \times X_{j} \times S\right)$

where $F_{\text {Monot(i) }}(t)$ is the VOC emission flux for a given plant species $j, X_{j}$ is the species cover rate and $n(=3)$ is the number of species considered in the ecosystem.

\section{Statistical analyses}

Descriptive statistics have been done on microclimatic, physiological, and modelled 20 data either for each measurement day or for the overall data. Test for homogeneity of variances (Levene test) has been performed before to apply the F-ANOVA test. If variances were unequal then the Welch-ANOVA test was applied (significance level $p \leq 00: 05)$. All statistical tests and graphs were performed by using the statistical package STATISTICA 7.0 (StatSoft, Inc., Tulsa, OK-USA). All data were showed as mean \pm S.D.

\section{BGD}

6, 1747-1776, 2009

Modelling of gas exchange and monotepene fluxes

M. Vitale et al.

Title Page

Abstract

Introduction

Conclusions

Tables

References

Figures

14

$\rightarrow$

4

Back

Close

Full Screen / Esc

Printer-friendly Version

Interactive Discussion 


\section{Results}

\subsection{Gas exchanges modelling}

Net photosynthesis trends $\left(P_{\mathrm{NET}}\right)$ simulated for the 2007 highlight a bell shape (Fig. 2), which reaches the maximum mean values during the summer months, although each 5 species shows different absolute monthly maximum values $(1.74 \pm 0.05,3.39 \pm 0.36$, and $3.98 \pm 0.16 \mathrm{gC} \mathrm{m}^{-2} \mathrm{~d}^{-1}$ for $Q$. ilex, $P$. latifolia and $A$. unedo, respectively). Similarly, leaf transpiration $(E)$ shows different absolute maximum values among species, whereas $Q$. ilex has the highest values of $E\left(1712.42 \pm 122.88 \mathrm{~g} \mathrm{H}_{2} \mathrm{O} \mathrm{m}^{-2} \mathrm{~d}^{-1}\right)$ than other two species $\left(899.74 \pm 54.46\right.$ and $377.04 \pm 16.29 \mathrm{~g} \mathrm{H}_{2} \mathrm{O} \mathrm{m}^{-2} \mathrm{~d}^{-1}$, $P$. latifolia and $A$. unedo, respectively) (Fig. 2).

In the Accent-VOCBAS campaign (May and June) modelled $P_{\mathrm{NET}}$ data show an increasing trend for plant species due to the optimal growth conditions and to the absence of drought stress in the study site; in particular, $Q$. ilex shows diurnal average values of $P_{\mathrm{NET}}$ as $1.67 \pm 0.08 \mathrm{gC} \mathrm{m}^{-2} \mathrm{~d}^{-1}$ in May. whereas $P$. latifolia and $A$. unedo have $2.39 \pm 0.30$ and $3.12 \pm 0.27 \mathrm{gC} \mathrm{m}^{-2} \mathrm{~d}^{-1}$, respectively. Furthermore, $E$ values are $1087.25 \pm 170.50,899.74 \pm 54.46$ and $373.47 \pm 21.76 \mathrm{~g} \mathrm{H}_{2} \mathrm{O} \mathrm{m}^{-2} \mathrm{~d}^{-1}$ for $Q$. ilex, $P$. latifolia and $A$. unedo, respectively.

\subsection{Monoterpene flux modelling}

Results show the higher monthly total monoterpene flux for $Q$. ilex $20 \quad\left(9582 \pm 1271 \mu \mathrm{g} \mathrm{m}^{-2}\right.$ soil $\left.\mathrm{h}^{-1}\right)$ than the other two species (Fig. 3), whereas monoterpene flux is negligible for $A$. unedo $\left(632 \pm 67\right.$ and $42 \pm 5 \mu \mathrm{g} \mathrm{m}^{-2}$ soil $\mathrm{h}^{-1}, P$. latifolia and $A$. unedo, respectively). Further, it is note to worthy that $Q$. ilex have monoterpene fluxes one factor higher than $P$. latifolia.

During the Accent-VOCBAS campaign period the increasing monoterpene fluxes 25 show average values of $4300 \pm 1538,383 \pm 121$ and $23 \pm 7 \mu \mathrm{g} \mathrm{m}^{-2}$ soil $\mathrm{h}^{-1}$, in $Q$. ilex, P. latifolia and $A$. unedo, respectively (Fig. 4).
BGD

6, 1747-1776, 2009

Modelling of gas exchange and monotepene fluxes

M. Vitale et al.

Title Page

Abstract

Introduction

Conclusions

Tables

References

Figures

14

$\rightarrow$

4

Back

Close 
Finally, the total monoterpene emission TE $\left(\mathrm{Kg} \mathrm{h}^{-1}\right)$ calculated for May-June months was also modelled by considering the coverage area $S$ of $464 \mathrm{Km}^{2}$ of the Castelporziano estate (Della Rocca et al., 2001), associated to the phyto-association of Viburno-Quercetum ilicis ([Br.-BI. 36] Rivas Martinez, 1975), and weighted for each 5 coverage area of the considered species (Fares et al., 2009). Q. ilex contribution was quantified to be $3204.77 \mathrm{Kg} \mathrm{h}^{-1}$, P. latifolia was $210.01 \mathrm{Kg} \mathrm{h}^{-1}$ and $A$. unedo was $20.26 \mathrm{Kg} \mathrm{h}^{-1}$, and a comprehensive value of $3435.04 \mathrm{Kg} \mathrm{h}^{-1}$. The overall monoterpene flux modelled for the 2007 (January-December) amounted to $12.54 \times 10^{3} \mathrm{Kg} \mathrm{h}^{-1}$, where contributions of the species considered here were $94.5 \%$ Q. ilex, $5.0 \%$ P. latifolia and $0.5 \%$ A. unedo.

\subsection{Comparisons between measured and modelled values}

In the inter-comparison exercises for the $\mathrm{C}$ assimilation rates during the Accent-Biaflux and VOCBAS 2007 field campaign, we have considered the Gross Primary Production (GPP) instead of Net Primary Production (NPP) when modelled data were compared with those measured by eddy covariance technique. Modelled GPP diurnal data by MOCA model of the three species considered here have been averaged, whereas GPP data of the eddy covariance measurements have been weighted for the coverage of the three species amounting to $52 \%$ of the study site. Figure 5 shows modelled and measured GPP values taking into account these corrections. Modelled GPP values overcame of $20-30 \%$ the measured ones (Fig. 5) with a statistical correlation $r=0.62(p<0.01)$, although diurnal averaged values for the measurement campaign period were $7.98 \pm 0.20$ and $6.00 \pm 1.46 \mathrm{gC} \mathrm{m}^{-2} \mathrm{~d}^{-1}$, modelled and measured data respectively.

Modelled monoterpene fluxes were compared with those directly measured during the Accent-VOCBAS campaign by disjunct eddy covariance method. Modelled average value corrected for the coverage of each species (Fares et al., 2009) was analogous to the measured one $229.02 \mu \mathrm{g} \mathrm{g}_{\mathrm{DW}}^{-1} \mathrm{~h}^{-1}$ vs. $229 \mu \mathrm{g} \mathrm{g}_{\mathrm{DW}}^{-1} \mathrm{~h}^{-1}$ (Davison et al., 2009). The

BGD

$6,1747-1776,2009$

Modelling of gas exchange and monotepene fluxes

M. Vitale et al.

Title Page

Abstract

Introduction

Conclusions

Tables

References

Figures

14

$\rightarrow$

4

Back

Close

Full Screen / Esc

Printer-friendly Version

Interactive Discussion 
time integration of monoterpene flux with a daily time-step performed by MOCA through the Runge-Kutta time interpolation of 4 th order, allowed to minimize errors that could derive by adoption of a different time step respect to the hourly-based variations of the measured monoterpene flux.

BGD

$6,1747-1776,2009$

\section{Modelling of gas exchange and monotepene fluxes}

M. Vitale et al. growing in the dune ecosystem of Castelporziano estate, allowed to characterise the patterns of gas exchange and BVOC emission from several Mediterranean plants, ideally linked to previous international measurements campaigns carried out on the same 10 site at the end of the 90's (Seufert et al., 1997). Modelling exercise made here simulated carbon assimilation and leaf transpiration processes without the drought stress characterising the Mediterranean summer period. Moreover, algorithms used for calculating the emission rates of total monoterpenes and their cumulated values (Simon et al., 2006) provided well corresponding values with measured ones.

15 However, modelling exercise highlighted also several difficulties for simulating these processes, which will be discussed below.

(a) Comparisons between measured and simulated GPP and monoterpenes

Comparisons between measured and modelled variables suffer of the nonhomogeneity of the study site. Because it is located on the behind of the first dune series, it was characterised by a prevalence of local sea-land breeze circulation by S-SW winds blowing during the day under prevailing high pressure conditions occurred during the campaign (Fares et al., 2009); this condition could affect measurements of gas exchange and VOC emissions by eddy covariance technique (Matteucci, G., personal communication, 2008). Furthermore, only a few attempts at scaling emission in a suitable way to use process-based models at the canopy level can be found in the literature (Baldocchi et al., 1999; Harley et al., 2004). These studies show that the distribu-

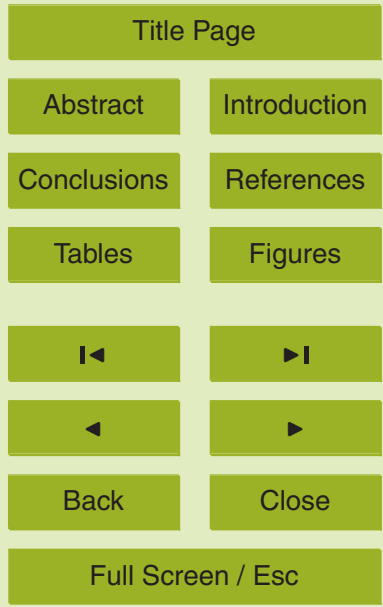

Printer-friendly Version

Interactive Discussion 
tions of environmental conditions as well as foliage properties are important for scaling emission from the leaf to the canopy. The scaling problem has been considered in the MOCA model taking into consideration some structural parameters as the foliar density $D$, the escape efficiency $r_{o}$, and the seasonal foliar biomass correction factor $C_{D}$ 5 (Owen and Hewitt, 2000). Further model adjustments could justify direct interventions on key sub-modules given the observed differences between modelled and measured GPP values, although the averaged values concerning the measurement period (MayJune) were similar $\left(7.98 \pm 0.20\right.$ and $6.00 \pm 1.46 \mathrm{gC} \mathrm{m}^{-2} \mathrm{~d}^{-1}$ for modelled and measured data, respectively). Additionally, recently developed coupled atmosphere - biosphere 10 global vegetation models showed an NPP data ranging 300 to $400 \mathrm{gC} \mathrm{m}^{-2} y^{-1}$ for the Central Italy (based on data of evergreen forests of the Castelporziano site) (Krinner et al., 2005), which were similar to MOCA average annual NPP estimations, ranging between 190 and $313 \mathrm{gC} \mathrm{m}^{-2} y^{-1}$ obtained for the vegetation maquis growing behind the first dune system of Castelporziano estate.

15 Estimates of isoprene and monoterpenes emission have mostly been parameterised on the basis of their dependence on light and temperature (Guenther et al., 1991, 1993, 1997). Emission algorithms such as ISOG97 (Guenther, 1997) are able to predict isoprene and monoterpene emissions (Ciccioli et al., 1997; Schuh et al., 1997; Staudt and Bertin, 1998) for many plant species but do not consider the ability of plants 20 to adapt their isoprenoid biosynthesis capacity dynamically according to changes of environmental parameters (Pétron et al., 2001; Staudt et al., 2003) or $\mathrm{CO}_{2}$ concentrations (Baraldi et al., 2004; Staudt et al., 2001). Such estimations could benefit from the development of models that take into account the physiological/phenological state of the leaves and the biochemical processes (Grote and Niinemets, 2008) lead-

25 ing to the formation of volatile isoprenoids such as SIM-BIN2 (Grote et al., 2006) and MEGAN (Guenther et al., 2006). More, the different basal emission factors used in the algorithms affected the emission values among species, although linkages with emission factor and phenology pattern (Ciccioli et al., 2003) and with physiological and physico-chemical constrains (Niinemets et al., 2004) have been made.

BGD

6, 1747-1776, 2009

\section{Modelling of gas exchange and monotepene fluxes}

M. Vitale et al.

Title Page

Abstract

Introduction

Conclusions

Tables

References

Figures

14

$\rightarrow$

4

Back

Close

Full Screen / Esc

Printer-friendly Version

Interactive Discussion 
However, modelled monoterpene emissions for $Q$. ilex $\left(6.50 \pm 2.25 \mu \mathrm{gg}_{\mathrm{DW}}^{-1} \mathrm{~h}^{-1}\right)$ are in agreement to the measured ones by Fares et al. (2009) with $9.39 \pm 4.50 \mu \mathrm{g} \mathrm{g}_{\mathrm{DW}}^{-1} \mathrm{~h}^{-1}$ and Street et al. (1997) with $6.8 \pm 2.9 \mu \mathrm{g} \mathrm{g}_{\mathrm{DW}}^{-1} \mathrm{~h}^{-1}$. Similarly, modelled values of $P$. latifolia $\left(0.63 \pm 0.20 \mu \mathrm{g} \mathrm{g}_{\mathrm{DW}}^{-1} \mathrm{~h}^{-1}\right)$ and $A$. unedo $\left(0.063 \pm 0.019 \mu \mathrm{g} \mathrm{g}_{\mathrm{DW}}^{-1} \mathrm{~h}^{-1}\right)$ are in ac5 cord with results reported in Fares et al. (2009) $0.98 \pm 0.30 \mu \mathrm{gg}_{\mathrm{DW}}^{-1} \mathrm{~h}^{-1}$ for $P$. latifolia and Owen et al. (1997), who measured monoterpene emissions between $0.70 \pm 0.60-0.37 \pm 0.30 \mu \mathrm{g} \mathrm{g}_{\mathrm{DW}}^{-1} \mathrm{~h}^{-1}$ and $0.21 \pm 0.08-0.07 \pm 0.01 \mu \mathrm{g} \mathrm{g}_{\mathrm{DW}}^{-1} \mathrm{~h}^{-1}$ for $P$. latifolia and $A$. unedo plants growing in the dune ecosystem of Castelporziano. The modelled monoterpene flux is also well matching with those reported by Simon et al. (2006) 10 calculated for the coastal Mediterranean vegetation of Berre-Marseilles area (France), and with measured ones by Davison et al. (2009). The adoption of the one-dimensional big-leaf approach as means for simulating physiological and structural parameters, and linking them to empirical algorithms for calculating monoterpene emission and flux, has been a suitable choice.

(b) Specific limitations of the MOCA model

- b.1 MOCA is a process-based model and, although it has a random function providing the daily cloudiness, it is not able to foresee sharp and short climate variations occurring in the measurement campaign, because climatic functions are linked to astronomical parameter and geographic coordinates. Moreover, MOCA is lacking of sub-modules that take into account the water availability in the soil at different deeps; as reported in Mereu et al. (2009), the soil water content measured at 10 and $100 \mathrm{~cm}$ showed different patterns of reduction, affecting thus the water supply toward the root apparata of plants (Alessio et al., 2004; Mereu et al., 2009), and their gas exchange rates (Asensio et al., 2007; Galmés et al., 2007). These restrictions limits the ability of MOCA to follow the hourly variation of emission rates or gas exchange rates, even though the resulting gas exchange rates are in accordance with literature when these were calculated as diurnal averages

\section{BGD}

$6,1747-1776,2009$

\section{Modelling of gas exchange and monotepene fluxes}

M. Vitale et al.

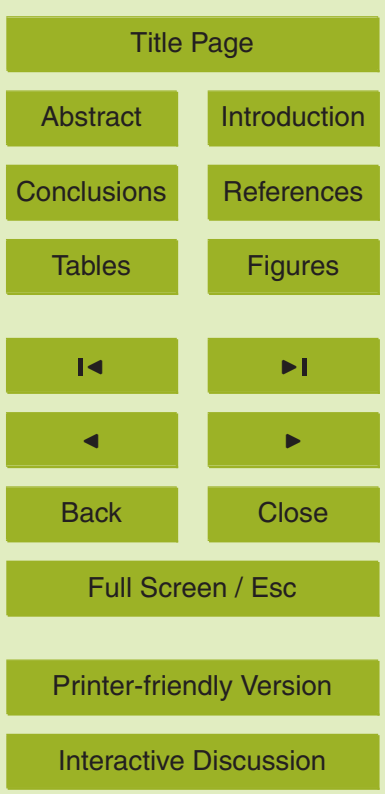

Interactive Discussion 
for the growth period of plant species considered here (Gratani and Ghia, 2002; Vitale and Manes, 2005b), due to the adoption of an appropriate interpolation algorithm for the time steps as the Runge-Kutta method.

BGD

6, 1747-1776, 2009

- b.2 A key-parameter is the foliar density - $D$, of plant species considered; in MOCA, $D$ is calculated by Eq. (11) and based on specific leaf area (SLA, constant) and leaf area index (LAI), the latter is calculated as function of net carbon assimilation $\left(P_{\mathrm{NET}}\right)$. Variation of foliar density has an effect on monoterpene flux estimation but also on gas exchange rates. A better calibration of SLA in MOCA (i.e. SLA equation expressed as time-based function) will allow to calculate more accurately the variables mentioned above.

- b.3 Tightly linked to $D$ parameter is the species-specific phenology. In this context the big-leaf approach adopted in MOCA is a good compromise between accuracy of simulations and multi-stratum models or 3-D structure-based models, which was not suitable for the modelling Mediterranean maquis, requiring much more information about structural variables (Beyschlag and Ryel, 2007; Omasa et al., 2007) than MOCA. On the other hand, the big-leaf approach is not suitable for modelling of physiological processes occurring in leaves of different ages as in Quercus ilex (Niinemets et al., 2006 and references therein reported) and in Phillyrea latifolia (Ogaya and Peñuelas, 2006), although the "old" leaves of plants growing at Castelporziano are a small portion of the $Q$. ilex's canopies (16\% of total leaves) as reported in Gratani and Bombelli (2000), which contrast with other studies reporting that leaves older than 1 year can comprise more than $50 \%$ of total canopy foliage in the Mediterranean evergreen-emitting species (Niinemets et al., 2005). A. unedo shed completely the "old" leaves after eleven months (Gratani

\section{Modelling of gas exchange and monotepene fluxes}

M. Vitale et al.

Title Page

Abstract

Introduction

Conclusions

Tables

References

Figures

14

$\rightarrow$

4

Back

Close

Full Screen / Esc

Printer-friendly Version

Interactive Discussion sion potentials in older leaves. Other data do demonstrate that monoterpene synthase activities are lower in 1-year-old leaves than in current year leaves (Fischbach et al., 2002), suggesting that the capacity for monoterpene emission de- \\ 1762}


clines with leaf age similarly to leaf photosynthetic potentials. Furthermore, to take into account the age-based decreasing monoterpene emission and the variation of the biomass density of plants will be one of future updating process in MOCA model for a better estimation of seasonal monoterpene fluxes.

\section{BGD}

$6,1747-1776,2009$

Finally, it should be emphasized about difficulty for scaling modelled results at different organisational structures and functions. In a non-homogenous study site, as the dune system of Castelporziano, some assumptions of homogeneity cannot be maintained because plant community is highly diversified in structure and functions, approaching to the maximisation of the environment resources in a limiting environment (Zavala, 2004). The latter is obtained by differentiating the rates of functional processes such as water uptake, carbon assimilation and secondary metabolism pathways (i.e. BVOC synthesis). In this frame, the dynamic simulation of these processes by a process-based model as MOCA requires additional information which often are not available or not easily measurable, although some alternative approaches have been done (Soil-Vegetation-Atmosphere Transfer models associated to remote sensing (Demarty et al., 2004) or eddy covariance (Olchev et al., 2008), Geographic Automata Systems (Torrens and Benenson, 2005; Bone et al., 2007), and size-structured numerical models (Tilman, 1988; Mouillot et al., 2001).

In conclusion, the MOCA model has some limitations for the reasons mentioned 20 above, but it is demonstrated to be an useful tool to simulate physiological processes and to integrate empirical algorithms (as Guenther's algorithms) for calculation of BVOC emissions and fluxes in a very complicated plant distributions and environmental conditions, necessitating of a low number of input data also.

Acknowledgements. The field campaign was supported by the VOCBAS and AC25 CENT/BIAFLUX programmes. We would also like to express our acknowledgements to the Scientific Committee of the Presidential Estate of Castelporziano and to its staff.

\section{Modelling of gas exchange and monotepene fluxes}

M. Vitale et al.

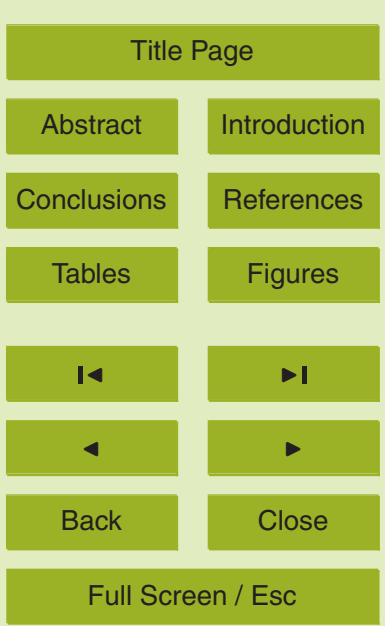

Printer-friendly Version

Interactive Discussion 


\section{References}

Aber, J. D. and Federer, C. A.: A generalized, lumped parameter model of photosynthesis, evapotranspiration and net primary production in temperate and boreal forest ecosystems, Oecologia, 92, 463-474, 1992.

5 Alessio, G. A., De Lillis, M., Brugnoli, E., and Lauteri, M.: Water sources and water-use efficiency in Mediterranean coastal dune vegetation, Plant Biology, 6, 350-357, 2004.

Anselmi, S., Chiesi, M., Giannini, M., Manes, F., and Maselli, F.: Estimation of Mediterranean forest transpiration and photosynthesis through the use of an ecosystem simulation model driven by remotely sensed data., Global Ecol. Biogeogr., 13, 371-380, 2004.

10 Asensio, D., Peñuelas, J., Ogaya, R., and Llusià, J.: Seasonal soil VOC exchange rates in a Mediterranean holm oak forest and their responses to drought conditions, Atmos. Environ., 41, 2456-2466, 2007.

Baldocchi, D. D., Fuentes, J. D., Bowling, D. R., Turnipseed, A. A., and Monson, R. K.: Scaling isoprene fluxes from leaves to canopies: test cases over a boreal aspen and a mixed species temperate forest., J. Appl. Meteorol., 38, 885-898, 1999.

Ball, J. T., Woodrow, I. E., and Berry, J. A.: A model predicting stomatal conductance and its contribution to the control of photosynthesis under different environmental conditions, in: Progress in Photosynthesis Research, vol. IV., edited by: Biggins, J., Martinus Nijhof Publishers, Dordrecht, The Netherlands, 221-234, 1987.

20 Baraldi, R., Rapparini, F., Oechel, W. C., Hastings, S. J., Bryant, P., Cheng, Y., and Miglietta, F.: Monoterpene emission responses to elevated $\mathrm{CO}_{2}$ in a Mediterranean-type ecosystem, New Phytol., 161, 17-21, 2004.

Beyschlag, W. and Ryel, R. J.: Canopy photosynthesis modelling, in: Functional Plant Ecology, edited by: Pugnaire, F. I. and Valladares, F., CRC Press, Chap., 627-654, 2007.

Björn, L. O. and Vogelmann, T. C.: Quantification of light, in: Photomorphogenesis in Plants, edited by: Kendrick, R. E., Kronenberg, G. H., and Kluwer, M., Dordrecht, The Netherlands, 17-25, 1993.

Bonan, G. B.: A land surface model (LSM version 1.0) for ecological, hydrological, and atmospheric studies: Technical description and User's guide, NCAR Tech. Note, NAR/TN417+STR, 150 pp., 1996.

Bone, C., Dragićević, S., and Roberts, A.: Evaluating forest management practices using a GIS-based cellular automata modeling approach with multispectral imagery, Environ. Model.
BGD

6, 1747-1776, 2009

\section{Modelling of gas exchange and monotepene fluxes}

M. Vitale et al.

Title Page

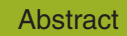

Introduction

Conclusions

References

Tables

Figures

14

I

4

Back

Close

Full Screen / Esc

Printer-friendly Version

Interactive Discussion 
Assess., 12, 105-118, 2007.

Cao, M. K. and Woodward, F. I.: Net primary and ecosystem production and carbon stocks of terrestrial ecosystems and their response to climatic change, Glob. Change Biol., 4, 185198, 1998.

5 Chiesi, M., Maselli, F., Moriondo, M., Fibbi, L., Bindi, M., and Running, S. W.: Application of BIOME-BGC to simulate Mediterranean forest processes, Ecol. Model., 206, 179-190, 2007.

Ciccioli, P., Brancaleoni, E., Frattoni, M., Marta, S., Brachetti, A., Vitullo, M., Tirone, G., and Valentini, R.: Relaxed eddy accumulation, a new technique for measuring emission and deposition fluxes of volatile organic compounds by capillary gas chromatography and mass spectrometry, J. Chromatogr. A., 985, 283-296, 2003.

Ciccioli, P., Fabozzi, C., Brancaleoni, E., Cecinato, A., Frattoni, M., Loreto, F., Kesselmeier, J., Schäfer, L., Bode, K., Torres, L., and Fugit, J. L.: Use of the isoprene algorithm for predicting the monoterpene emission from the Mediterranean holm oak Quercus ilex L.: Performance

15 and limits of this approach, J. Geophys. Res.-Atmos., 102, 23319-23328, 1997.

Dai, Y., Zeng, X., Dickinson, R. E., Baker, I., Bonan, G., Bosilovich, M., Dennig, S., Dirmeyer, P., Houser, P., Niu, G., Oleson, K., Schlosser, A., and Yang, Z.-L.: The Common Land Model (CLM), B. Am. Meteorol. Soc., 84, 1013-1023, 2003.

Davison, B., Taipale, R., Langford, B., Misztal, P., Fares, S., Matteucci, G., Loreto, F., Cape, J. N., Rinne, J., and Hewitt, C. N.: Concentrations and emissions of volatile organic compounds above a Mediterranean ecosystem in Western Italy, Biogeoscience, accepted, 2009.

de Pury, D. G. G. and Farquhar, G. D.: Simple scaling of photosynthesis from leaves to canopies without the errors of big-leaf model, Plant Cell Environ., 20(5), 537-557, 1997.

De Wit, C. T., Goudriaan, J., van Laar, H. H., Penning de Vries, F. W. T., Rabbinge, R., van Keulen, H., Louwerse, W., Sibma, L., and de Jonge, C.: Simulation of assimilation, respiration and transpiration of crops, Pudoc, Wageningen, The Netherlands, 141 pp., 1978.

Della Rocca, A. B., Pignatti, S., Mugnoli, S., and Bianco, P. M.: La carta della vegetazione della Tenuta di Castelporziano, in: II sistema ambientale della Tenuta Presidenziale di Castelporziano, Ricerche sulla complessità di un ecosistema forestale costiero mediterraneo, Accademia Nazionale delle Scienze detta dei Quaranta, 2, 709-747, 2001 (Abstract in English).

Demarty, J., Ottle, C., Braud, I., Olioso, A., Frangi, J. P., Bastidas, L. A., and Gupta, H. V.: Using a multi-objective approach to retrieve information on surface properties used in a SVAT

\section{BGD}

$6,1747-1776,2009$

\section{Modelling of gas exchange and monotepene fluxes}

M. Vitale et al.

Title Page

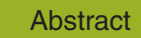

Introduction

Conclusions References

Tables Figures

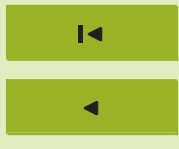

$\rightarrow 1$

Back

Close

Full Screen / Esc

Printer-friendly Version

Interactive Discussion 
model, J. Hydrol., 287(1-4), 214-236, 2004.

Dickinson, R. E., Shaikh, M., Bryant, R., and Graumlich, L.: Interactive canopies for a climate model, J. Climate, 11, 2823-2836, 1998.

Diffenbaugh, N. S., Pal, J. S., Trapp, R. J., and Giorgi, F.: Fine-scale processes regulate the response of extreme events to global climate change, P. Natl. Acad. Sci. USA , 102(44), 15774-15778, 2005.

Dumergues, L.: Inventaire des émissions naturelles en région méditerranéenne: application à l'établissement de cadastres détaillés de la zone Marseille-Berre dans le cadre du projet ESCOMPTE, Détermination sur site de facteurs d'émission spécifiques à la zone d'étude,

10 Thèse INPT, Toulouse, France, no. 2060, 2003.

El Maayar, M. and Chen, J. M.: Spatial scaling of evapo-transpiration as affected by heterogeneities in vegetation, topography, and soil texture, Remote Sens. Environ., 102, 33-51, 2006.

Fares, S., Mereu, S., Scarascia Mugnozza, G., Vitale, M., Manes, F., Frattoni, M., Ciccioli, P., 15 and Loreto, F.: The ACCENT-VOCBAS field campaign on biosphere-atmosphere interactions in a Mediterranean ecosystem of Castelporziano (Rome): site characteristics, climatic and meteorological conditions, and eco-physiology of vegetation, Biogeosciences Discuss., 6 , 1185-1227, 2009, http://www.biogeosciences-discuss.net/6/1185/2009/.

20 Fischbach, R. J., Staudt, M., Zimmer, I., Rambal, S., and Schnitzler, J.-P.: Seasonal pattern of monoterpene synthase activities in leaves of the evergreen tree Quercus ilex, Physiol. Plantarum, 114, 354-360, 2002.

Galmés, J., Flexas, J., Savé, R., and Medrano, H.: Water relations and stomatal characteristics of Mediterranean plants with different growth forms and leaf habits: responses to water stress and recovery, Plant Soil, 290(1-2), 139-155, 2007.

Goldstein, A. H., McKay, M., Kurpius, M. R., Schade, G. W., Lee, A., Holzinger, R., and Rasmussen, R. A.: Forest thinning experiment confirms ozone deposition to forest canopy is dominated by reaction with biogenic VOCs, Geophys. Res. Lett., 31, L22106, doi:10.1029/2004GL021259, 2004.

30 Goudriaan, J. and van Laar, H. H.: Modelling potential crop growth processes, Kluwer Academic Publishers, Dordrecht, The Netherlands, 238 pp., 1994.

Gratani, L. and Bombelli, A.: Correlation between leaf age and other leaf traits in three Mediterranean maquis shrub species: Quercus ilex, Phillyrea latifolia and Cistus incanus, Environ.

BGD

6, 1747-1776, 2009

\section{Modelling of gas exchange and monotepene fluxes}

M. Vitale et al.

Title Page

Abstract

Introduction

Conclusions

References

Tables

Figures

14

$\rightarrow 1$

4

Back

Close

Full Screen / Esc

Printer-friendly Version

Interactive Discussion 
Exp. Bot., 43, 141-153, 2000.

Gratani, L. and Ghia, E.: Changes in morphological and physiological traits during leaf expansion of Arbutus unedo, Environ. Exp. Bot., 48, 51-60, 2002.

Grote, R. and Niinemets, U.: Modelling volatile isoprenoid emissions - a story with split ends, Plant Biology, 10, 8-28, 2008.

Grote, R.: Sensitivity of volatile monoterpene emission to changes in canopy structure - a model based exercise with a process-based emission model, New Phytol., 173, 550-561, 2006.

Guenther, A., Geron, C., Pierce, T., Lamb, B., Harley, P., and Fall, R.: Natural emissions of nonmethane volatile organic compounds carbon monoxide, and oxides of nitrogen from North America, Atmos Environ., 34, 2205-2230, 2000.

Guenther, A., Zimmerman, P. R., Harley, P. C., Monson, R. K., and Fall, R.: Isoprene and monoterpene emission rate variability: model evaluations and sensitivity analyses, J. Geophys. Res., 93, 12609-12617, 1993.

15 Guenther, A. B., Monson, R. K., and Fall, R.: Isoprene and monoterpene emission rate variability: observations with eucalyptus and emission rate algorithm development, J. Geophys. Res., 96(D6), 10799-10808, 1991.

Guenther, A. B.: Seasonal and spatial variations in natural volatile organic compound emissions, Ecol. Appl., 7, 34-45, 1997.

20 Harley, P. C., Thomas, R. B., Reynolds, J. F., and Strain, B. R.: Modelling photosynthesis of cotton grown in elevated $\mathrm{CO}_{2}$, Plant Cell Environ., 15, 271-282, 1992.

Harley, P., Vasconcellos, P., Vierling, L., Pinheiro, C. C. D. S., Greenberg, J., Guenther, A., Klinger, L., De Almeida, S. S., Neill, D., Baker, T., Phillips, O., and Malhi, Y.: Variation in potential for isoprene emissions among neotropical forest sites, Glob. Change Biol., 10, 630650, 2004.

Jarvis, P. G.: Scaling processes and problems, Plant Cell Environ., 18, 1079-1089, 1995.

Jump, A. S. and Peñuelas, J.: Running to stand still: adaptation and the response of plants to rapid climate change, Ecol. Lett., 8, 1010-1020, 2005.

Kesselmeier, J. and Staudt, M.: Biogenic volatile organic compounds (VOC): an overview on emission, physiology and ecology, J. Atmos. Chem., 33, 23-88, 1999.

Krinner, G., Viovy, N., de Noblet-Ducoudre, N., Ogée, J., Polcher, J., Friedlingstein, P., Ciais, P., Stitch, S., and Prentice, C.: A dynamic global vegetation model for studies of the coupled atmosphere biosphere system, Global Biogeochem. Cy., 19, GB1015,
BGD

6, 1747-1776, 2009

\section{Modelling of gas exchange and monotepene fluxes}

M. Vitale et al.

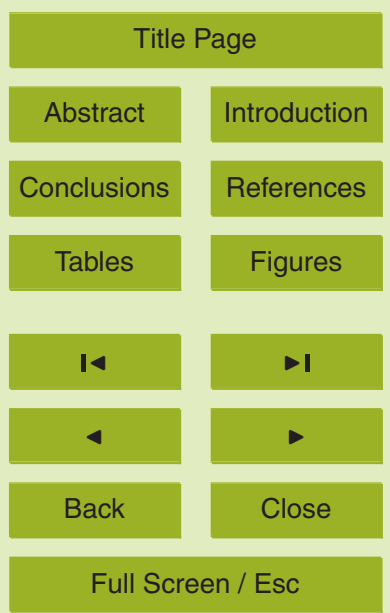

Printer-friendly Version

Interactive Discussion 
doi:10.1029/2003GB002199, 2005.

Lai, C.-T., Katul, G., Butnor, J., Ellsworth, D., and Oren, R.: Modelling nighttime ecosystem respiration by a constrained source optimization method, Glob. Change Biol., 8, 124-141, 2002.

5 Leuning, R., Kelliher, F. M., Pury, D. G. G., and Schulze, E.-D.: Leaf nitrogen, photosynthesis, conductance and transpiration: scaling from leaves to canopies, Plant Cell Environ., 18, 1183-1200, 1995.

Lloyd, J. and Farquhar, G. D.: The $\mathrm{CO}_{2}$ dependence of photosynthesis, plant growth responses to elevated atmospheric $\mathrm{CO}_{2}$ concentration and their interaction with soil nutrient status I.

10 General principles and forest ecosystems, Funct. Ecol., 10, 4-32, 1996.

Luo, Y., Medlyn, B., Hui, D., Ellsworth, D., Reynolds, J., and Katul, G.: Gross primary productivity in Duke Forest: modeling synthesis of $\mathrm{CO}_{2}$ experiment and eddy-flux data, Ecol. Appl., 11, 239-252, 2001.

McMurtrie, R. E. and Landsberg, J. J.: Using a simulation model to evaluate the effects of water 15 and nutrients on the growth and carbon partitioning of Pinus radiata, Forest Ecol. Manag., 52, 243-260, 1992.

Mereu, S., Salvatori, E., Fusaro, L., Gerosa, G., Muys, B., and Manes, F.: A whole plant approach to evaluate the water use of Mediterranean maquis species in a coastal dune ecosystem, Biogeoscience, accepted, 2009.

20 Mouillot, F., Rambal, S., and Lavorel, S.: A generic process-based Simulator for meditERranean fire-prone landscapes (SIERRA): Design and validation exercises, Forest Ecol. Manag., 147, 75-97, 2001.

Niinemets, Ü., Cescatti, A., Rodeghiero, M., and Tosens, T.: Complex adjustments of photosynthetic potentials and internal diffusion conductance to current and previous light availabilities and leaf age in Mediterranean evergreen species Quercus ilex, Plant Cell Environ., 29, 1159-1178, 2006.

Niinemets, Ü., Cescatti, A., Rodeghiero, M., and Tosens, T.: Leaf internal diffusion conductance limits photosynthesis more strongly in older leaves of Mediterranean evergreen broadleaved species, Plant Cell Environ., 28, 1552-1566, 2005.

30 Niinemets, Ü., Loreto, F., and Reichstein, M.: Physiological and physicochemical controls on foliar volatile organic compound emissions, Trends Plant Sci., 9, 180-186, 2004.

Ogaya, R. and Peñuelas, J.: Contrasting foliar responses to drought in Quercus ilex and Phillyrea latifolia, Biol. Plantarum, 50(3), 373-382, 2006.

BGD

6, 1747-1776, 2009

\section{Modelling of gas exchange and monotepene fluxes}

M. Vitale et al.

Title Page

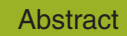

Introduction

Conclusions

References

Tables

Figures

14

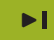

4

Back

Close

Full Screen / Esc

Printer-friendly Version

Interactive Discussion 
Olchev, A., Ibrom, A., Ross, T., Falk, U., Rakkibu, G., Radler, K., Grote, S., Kreilein, H., and Gravenhorst, G.: A modelling approach for simulation of water and carbon dioxide exchange between multi-species tropical rain forest and the atmosphere, Ecol. Model., 212, 122-130, 2008.

5 Omasa, K., Hosoi, F., and Konishi, A.: 3-D lidar imaging for detecting and understanding plant responses and canopy structure, J. Exp. Bot., 58(4), 881-898, 2007.

Owen, S. M. and Hewitt, C. N.: Extrapoling branch enclosure measurements to estimates of regional scale biogenic VOC fluxes in the north-western Mediterranean basin, J. Geophys. Res., 105(D9), 11573-11583, 2000.

10 Owen, S., Boissard, C., Street, R. A., Duckham, C., Csiky, O., and Hewitt, C. N.: Screening of 18 Mediterranean plant species for volatile organic compound emissions, Atmos. Environ., 31(SI), 101-117, 1997.

Parmesan, C.: Ecological and Evolutionary Responses to Recent Climate Change, Annu. Rev. Ecol. Evol. S., 37, 637-69, 2006.

Pétron, G., Harley, P., Greenberg, J., and Guenther, A.: Seasonal temperature variations influence isoprene emission, Geophys. Res. Lett., 28, 1707-1710, 2001.

Pio, C. A., Nunes, T. V., and Brito, S.: Volatile hydrocarbon emissions from common and native species of vegetation in Portugal, in:, Proceedings of joint CEC/BIATEX of EUROTRAC Workshop, General Assessment of Biogenic Emissions and Deposition of Nitrogen Compounds, Sulphur Compounds and Oxidants in Europe, Environmental Research Programme, edited by: Slanina, J., Angeletti, G., and Beilke, S., E. Guyot SA, Brussels, CEC Air Pollution Research Report 47, ISBN 2-87263-095-3, 291-298, 1993.

Running, S. W. and Hunt Jr., E. R.: Generalization of a forest ecosystem model for other biomes, BIOME-BGC, and an application for global-scale models, in: Scaling Physiological Processes: Leaf to Globe, edited by: Ehleringer, J. R. and Fields, C., Academic Press, San Diego, CA, USA, 141-158, 1993.

Sampson, D. A., Janssens, I. E., and Ceulemans, R.: Simulated soil $\mathrm{CO}_{2}$ efflux and net ecosystem exchange in a 70-year-old Belgian Scots pine stand using the process model SECRETS, Ann. For. Sci., 58, 31-46, 2001.

30 Schuh, G., Heiden, A. C., Hoffmann, T., Kahl, J., Rockel, P., Rudolph, J., and Wildt, J.: Emissions of volatile organic compounds from sunflower and beech: Dependence on temperature and light intensity, J. Atmos. Chem., 27, 291-318, 1997.

Schwalm, C. R. and Ek, A. R.: Climate change and site: relevant mechanisms and modelling

BGD

6, 1747-1776, 2009

\section{Modelling of gas exchange and monotepene fluxes}

M. Vitale et al.

Title Page

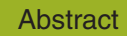

Introduction

Conclusions

References

Tables

Figures

14

4

Back

Close

Full Screen / Esc

Printer-friendly Version

Interactive Discussion 
techniques, Forest Ecol. Manag., 150, 241-257, 2001.

Schymanski, S. J., Roderick, M. L., Sivapalan, M., Hutley, L. B., and Beringer, J.: A test of the optimality approach to modelling canopy properties and $\mathrm{CO}_{2}$ uptake by natural vegetation, Plant Cell Environ., 30, 1586-1598, 2007.

5 Sellers, P. J., Dickinson, R. E., Randall, D. A., Betts, A. K., Hall, F. G., Berry, J. A., Collatz, G. J., Denning, A. S., Mooney, H. A., Nobre, C. A., Sato, N., Field, C. B., and HendersonSellers, A.: Modelling the exchanges of energy, water, and carbon between continents and the atmosphere, Science, 275, 502-509, 1997.

Seufert, G., Bartzis, J., Bomboi, T., Ciccioli, P., Cieslik, S., Dlugi, R., Foster, P., Hewitt, C. N.,

10 Kesselmeier, J., Kotzias, D., Lenz, R., Manes, F., Perez Pastor, R., Steinbrecher, R., Torres, L., Valentini, R., and Versino, B.: An overview of the Castelporziano experiments. BEMA A European Commission project on Biogenic Emission in the Mediterranean Area, Atmos. Environ., 31(SI), 5-17, 1997.

Simon, V., Dumergues, L., Ponche, J.-L., and Torres, L.: The biogenic volatile organic com15 pounds emission inventory in France. Application to plant ecosystems in the Berre-Marseilles area (France), Sci. Total Environ., 372, 164-182, 2006.

Staudt, M. and Bertin, N.: Light and temperature dependency of the emission of cyclic and acyclic monoterpenes from holm oak (Quercus ilex L.) leaves, Plant Cell Environ., 21, 385395, 1998.

20 Staudt, M., Joffre, R., Rambal, S., and Kesselmeier, J.: Effect of elevated $\mathrm{CO}_{2}$ on monoterpene emission of young Quercus ilex trees and its relations to structural and ecophysiological parameters, Tree Physiol., 21, 437-445, 2001.

Staudt, M., Joffre, R., and Rambal, S.: How growth conditions affect the capacity of Quercus ilex leaves to emit monoterpenes, New Phytol., 158, 61-73, 2003.

Street, R. A., Owen, S., Duckham, S. C., Boissard, C., and Hewitt, C. N.: Effect of habitat and age on variations in volatile organic compounds (VOC) emission from Quercus ilex and Pinus pinea, Atmos. Environ., 31(SI), 89-100, 1997.

Tilman, D.: Monographs in Population Biology 26, Princeton University Press, Princeton, New Jersey, USA, 1988.

30 Tingey, D. T., Manning, M., Grothaus, L. C., and Burns, W. F.: Influence of light and temperature on monoterpene emission rates from Slash pine, Plant Physiol., 65, 797-801, 1980.

Torrens, P. and Benenson, I.: Geographic Automata Systems, Int. J. Geogr. Inf. Sci., 19(4), 385-412(28), 2005.

\section{Modelling of gas exchange and monotepene fluxes}

M. Vitale et al.

Title Page

Abstract

Introduction

Conclusions

References

Tables

Figures

14

$\rightarrow 1$

4

Back

Close

Full Screen / Esc

Printer-friendly Version

Interactive Discussion 
Vitale, M., Capogna, F., and Manes, F.: Resilience assessment on Phillyrea angustifolia L. maquis undergone to experimental fire through a big-leaf modelling approach, Ecol. Model., 203, 387-394, 2007.

Vitale, M., Gerosa, G., Ballarin-Denti, A., and Manes, F.: Ozone uptake by an evergreen

$5 \quad$ Mediterranean forest (Quercus ilex L.) in Italy. Part II: Flux modelling. Up scaling leaf to canopy ozone uptake by a process-based model, Atmos. Environ., 39, 3267-3278, 2005a.

Vitale, M. and Manes, F.: Role of changing environmental parameters in leaf gas exchange of Arbutus unedo L. assessed by field and laboratory measurements, Photosynthetica, 43(1), 99-106, 2005b.

10 Vitale, M., Scimone, M., Feoli, E., and Manes, F.: Modelling leaf gas exchanges as a function of temperature increase to predict trends of functional processes in Mediterranean Quercus ilex forest under climatic changes, Ecol. Model., 166, 123-134, 2003.

Wang, K.-Y., Kellomaki, S., Zha, T. S., and Peltola, H.: Component carbon fluxes and their contribution to ecosystem carbon exchange in a pine forest: an assessment based on eddy covariance measurements and an integrated model, Tree Physiol., 24, 19-34, 2004.

Wang, Y. P. and Jarvis, P. G.: Influence of crown structural properties on PAR absorption, photosynthesis, and transpiration in Sitka spruce: application of a model (MAESTRO, radiation and PSYN model), Tree Physiol., 7, 297-316, 1990.

Wang, Y. P. and Leuning, R.: A two-leaf model for canopy conductance, photosynthesis and partitioning of available energy I: Model description and comparison with a multi-layered model, Agr. Forest Meteorol., 91, 89-111, 1998.

Wang, Y. P., Leuning, R., Cleugh, H. A., and Coppin, P. A.: Parameter estimation in surface exchange models using non-linear inversion: how many parameters can we estimate and which measurements are most useful?, Glob. Change Biol., 7, 495-510, 2001.

Zavala, M. A.: Integration of drought tolerance mechanisms in Mediterranean sclerophylls: a functional interpretation of leaf gas exchange simulators, Ecol. Model., 176, 211-226, 2004.

BGD

$6,1747-1776,2009$

\section{Modelling of gas exchange and monotepene fluxes}

M. Vitale et al.

Title Page

Abstract

Introduction

Conclusions

References

Tables

Figures

14

-1

4

Back

Close

Full Screen / Esc

Printer-friendly Version

Interactive Discussion 
BGD

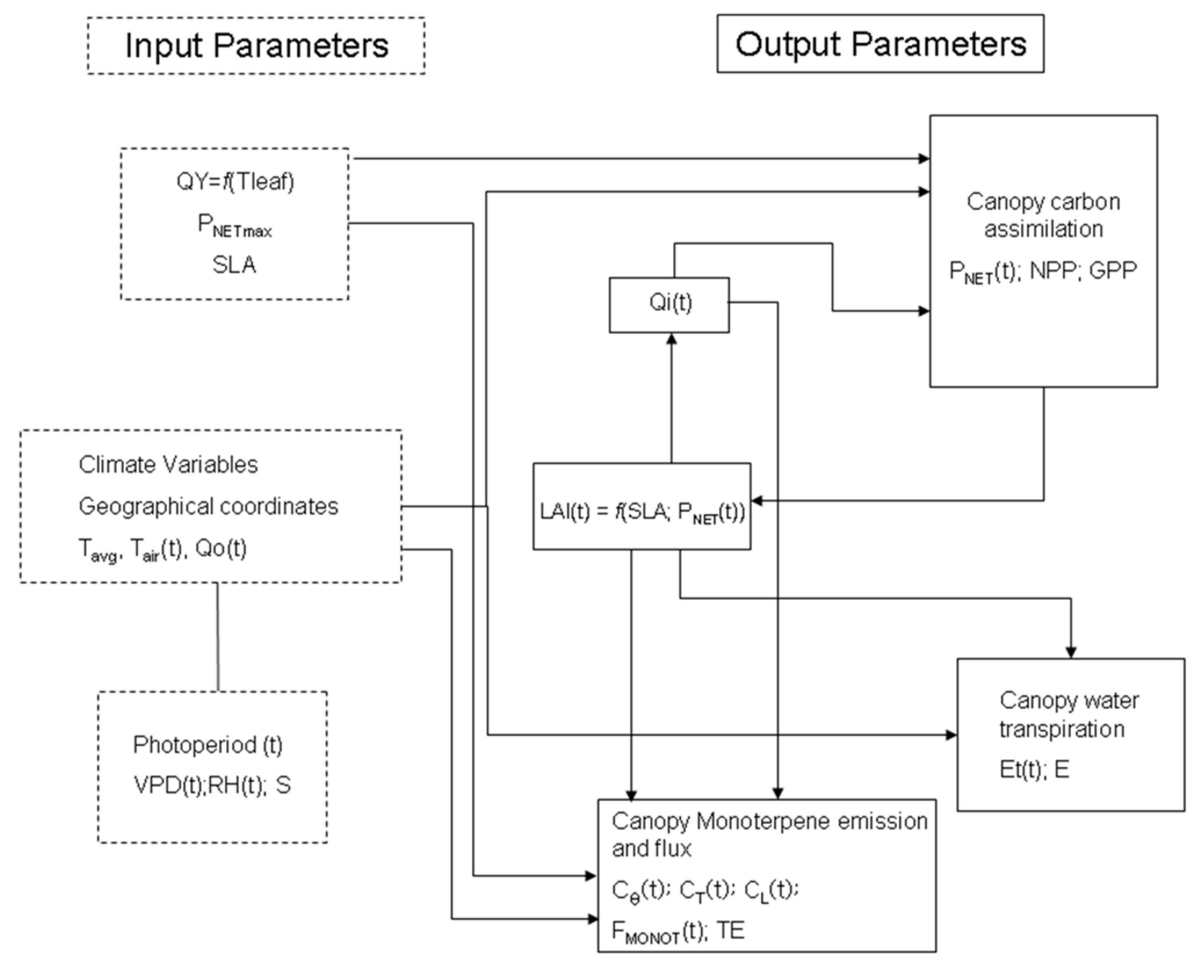

$6,1747-1776,2009$

\section{Modelling of gas exchange and monotepene fluxes}

M. Vitale et al.

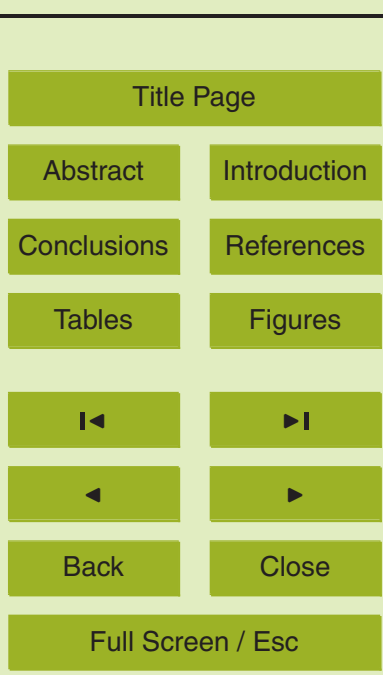

Fig. 1. Simplified scheme of the MOCA model showing the main components and their connections.

Printer-friendly Version

Interactive Discussion 


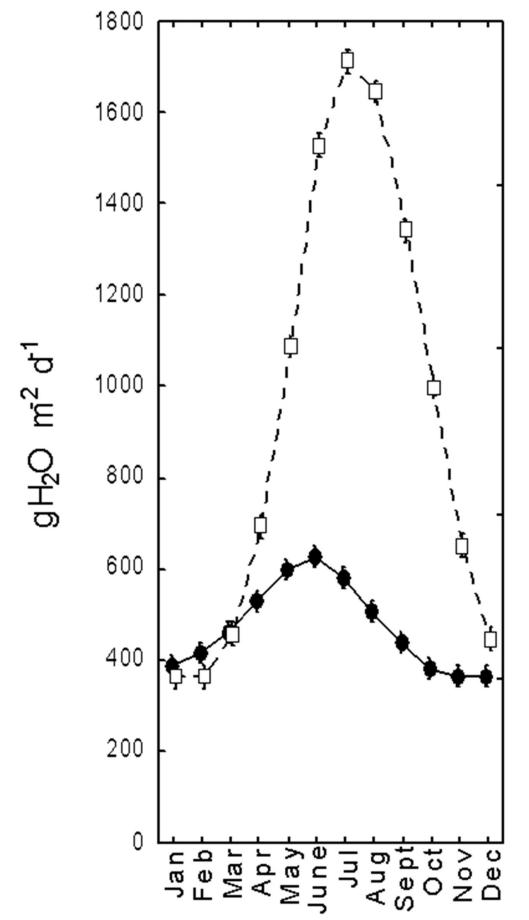

Q. ilex

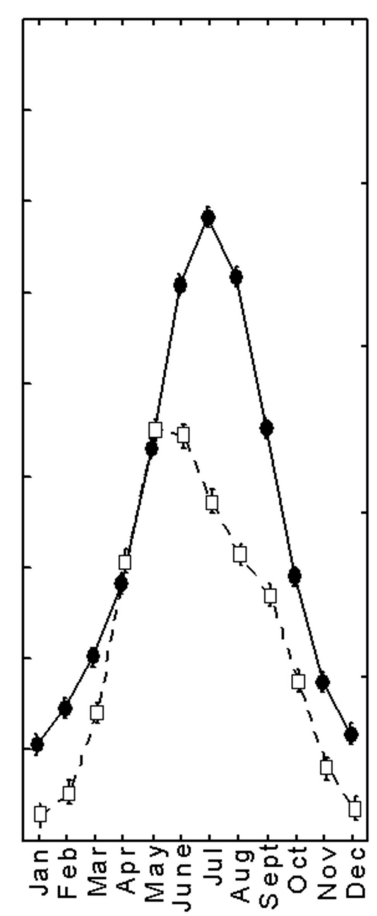

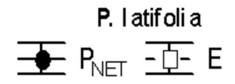

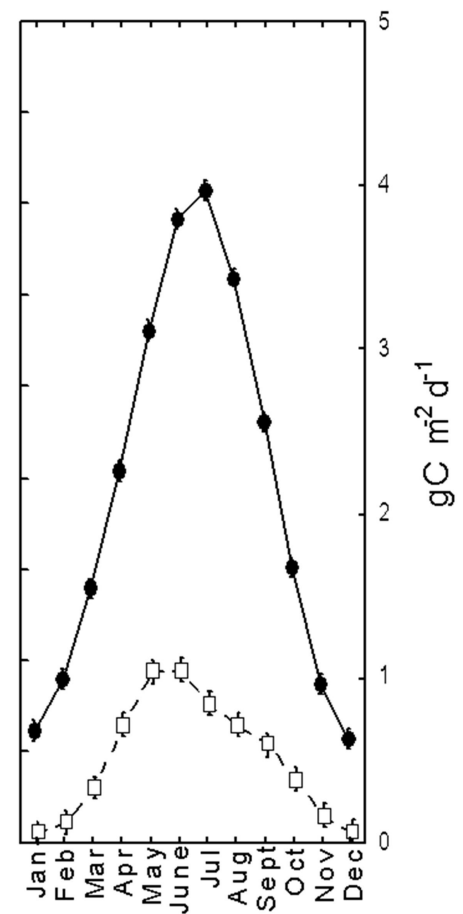

A unedo
BGD

6, 1747-1776, 2009

\section{Modelling of gas exchange and monotepene fluxes}

M. Vitale et al.

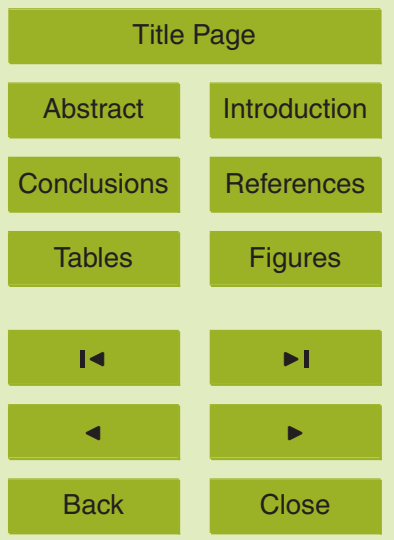

Full Screen / Esc

Printer-friendly Version

Interactive Discussion 
BGD

$6,1747-1776,2009$

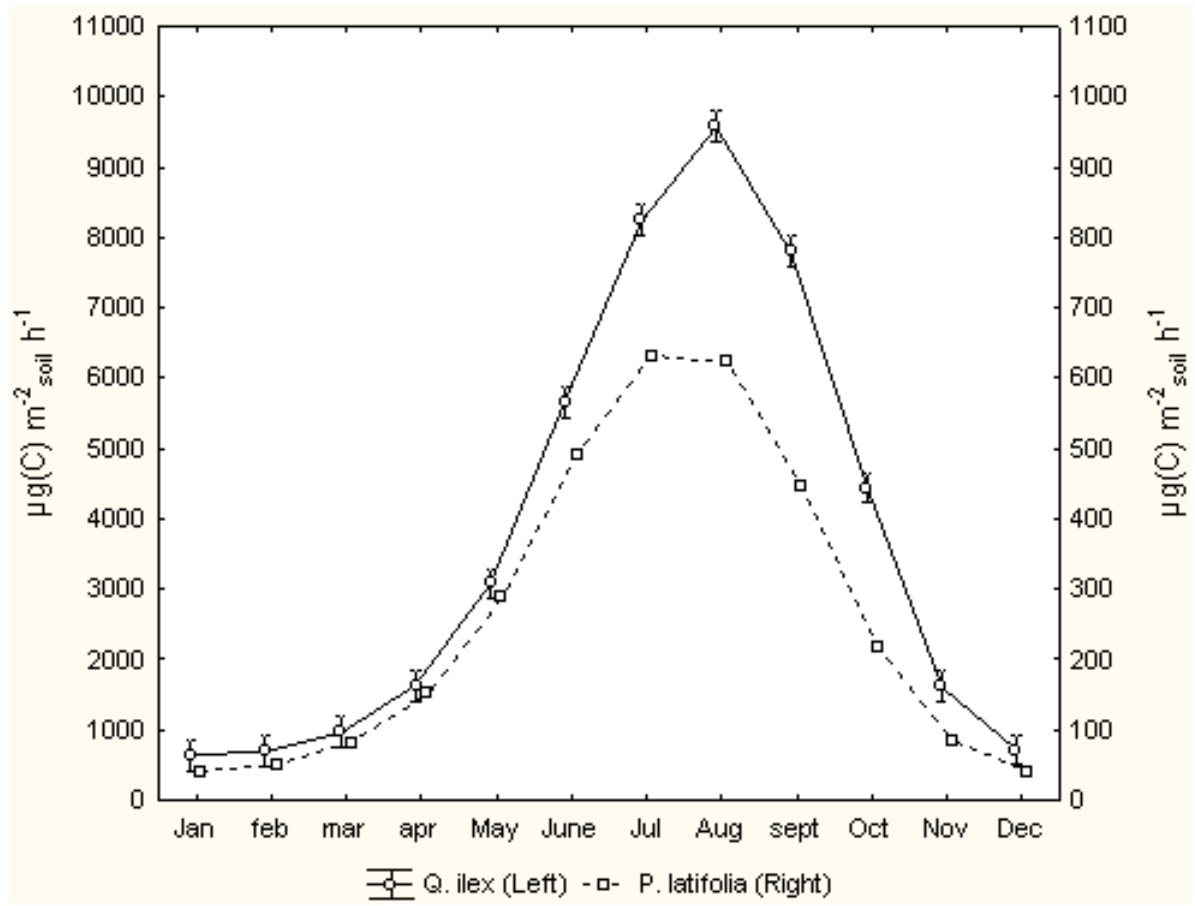

Fig. 3. Annual patterns of the monoterpene fluxes expressed as monthly averages for the 2007 for the three species. It is highlighted a prevalence of $Q$. ilex monoterpene flux with respect to other two.

\section{Modelling of gas exchange and monotepene fluxes}

M. Vitale et al.

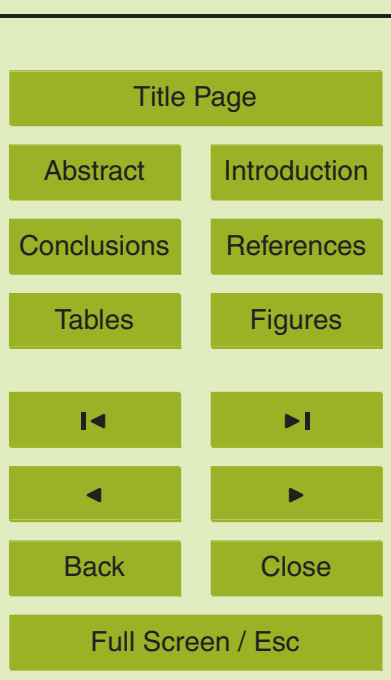

Printer-friendly Version

Interactive Discussion 
BGD

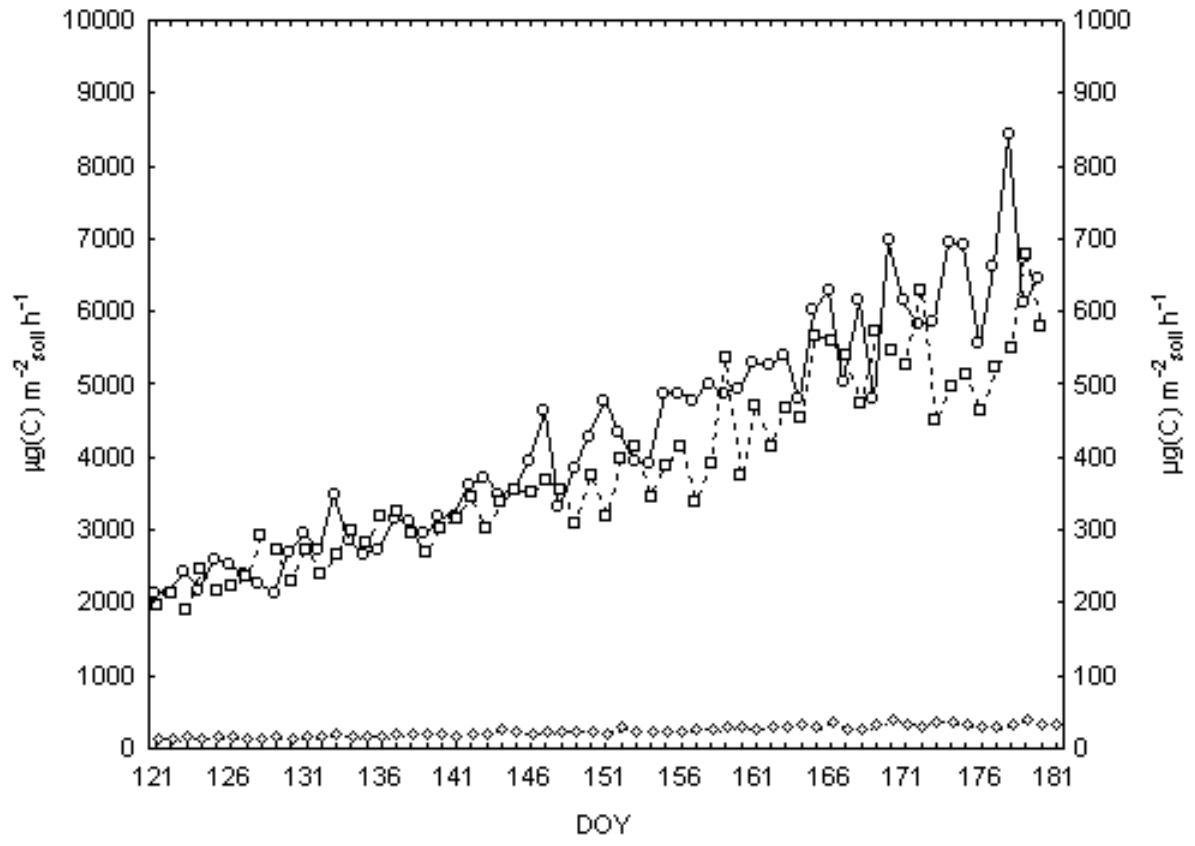

코 Q. ilex (Left) 모 P. latifolia (Right) 꼬. A. unedo (Right)

Fig. 4. Patterns of the monoterpene fluxes simulated in the Accent-VOCBAS campaign 2007. Although monoterpene fluxes show a similar trend for $Q$. ilex and $P$. latifolia, one should note that among species there is a difference of one magnitude order.
6, 1747-1776, 2009

\section{Modelling of gas exchange and monotepene fluxes}

M. Vitale et al.

Title Page

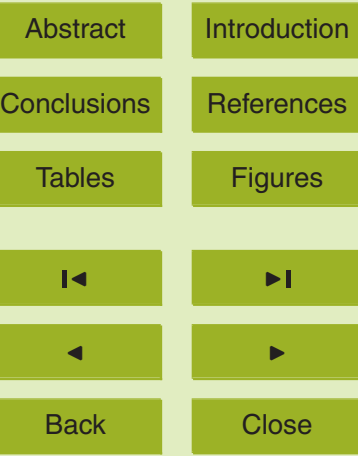

Full Screen / Esc

Printer-friendly Version

Interactive Discussion 


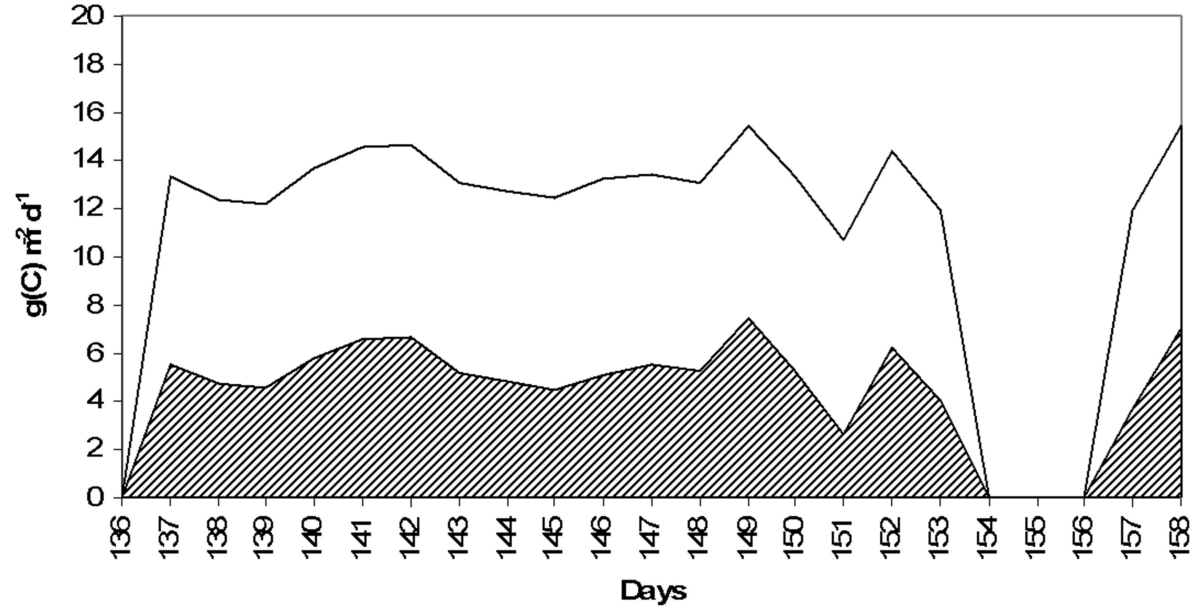

๒ GPP measured $\square$ GPP modelled

Fig. 5. Gross Primary Productivity (GPP) measured by eddy covariance technique and simulated by MOCA model. Simulated values are higher of about $30 \%$ than measured ones in a point-to-point comparison, although the average values of the overall campaign are similar.

\section{Modelling of gas exchange and monotepene fluxes}

M. Vitale et al.

Title Page

Abstract

Introduction

Conclusions

References

Tables

Figures

14

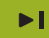

4

Back

\section{Full Screen / Esc}

Printer-friendly Version

Interactive Discussion 